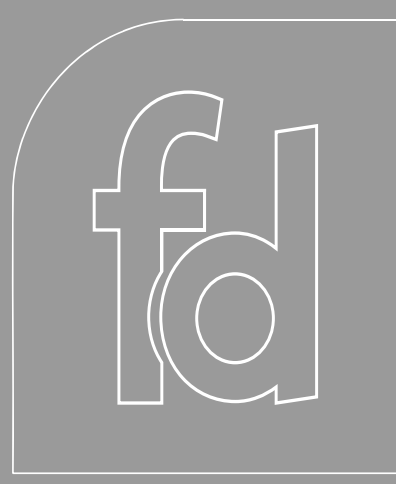

CONTENTS

From genomics to proteomics

Development of proteomic techniques

Proteomic techniques

Type 1 diabetes

Expert commentary

$\&$ five-year view

Key issues

References

Affiliations

\title{
Type 1 diabetes: entering the proteomic era
}

\author{
Wannes D'Hertog, Chantal Mathieu and Lut Overbergh ${ }^{\dagger}$
}

\begin{abstract}
During the last decade, a major breakthrough in the field of proteomics has been achieved. This review describes available techniques for proteomic analyses, both gel and non-gel based, particularly concentrating on relative quantific ation tec hniques. The principle of the different techniques is disc ussed, highlighting the advantages and drawbacks of recently available visualization methods in gel-based assays. In addition, recent developments for quantitative analysis in non-gel-based approaches are summanized. This review foc uses on applications in Type 1 diabetes. These mainly include proteomic studies on pancreatic islets in animal models and in the human situation. Also disc ussed are mass spectrometry-based studies on T-cells, and studies on the development of diagnostic markers for diabetic nephropathology by capillary electrophoresis coupled to mass spectrometry.
\end{abstract}

Expert Rev. Proteomics 3(2), 223-236 (2006)

\section{From genomics to proteomics}

The term proteome was first introduced in 1994 by Wilkins and coworkers in Siena, Italy [1]. Proteome refers to the already established terms genome and transcriptome, and describes all proteins present in a given cell or organism. Although researchers realized that a systematic analysis of the proteins expressed by a cell or organism would be essential to understand the mechanisms and pathways involved in all aspects of cell growth and differentiation many years earlier, it was only until the completion of the first genome projects that this proteome investigation boosted enormously. This was the start of the post-genomic era, where researchers realized that many processes occur in a cell from the transition from genome to proteome, which could not be explained solely by genomics and transcriptomics.

It is undoubtedly clear that the availability of the human genome has aided greatly to our understanding of many genetic disorders and is a great step forward in the diagnosis and treatment possibilities for their associated diseases. H owever, the majority of diseases, even if they are genetic, are not caused by a single mutation. Rather, they are a combinatorial effect of multiple genetic mutations or an unfavorable combination of common alleles. In addition, environmental factors may also contribute to initiation of the disease, which is true for Type 1 diabetes (T 1D). Concurrently with the sequencing of the human genome, RN A-based assays, such as microarrays and the real-time reverse transcriptase PCR technique, were a major research topic, both in fundamental research and in clinical diagnostics [2]. Although our knowledge of the pathways involved in many diseases greatly improved, no information whatsoever could be obtained from these RNA-based studies regarding the importance of translational regulation and the role of post-translational modifications (PT M s). M oreover, some authors proved a very poor correlation between mRNA levels and protein levels $[3,4]$. From this perspective, proteomics covers the real executing molecules that change expression in a diseased state or after application of a candidate medical compound.

The International Human Genome Sequencing Consortium has estimated that there are most likely 30,000-40,000 proteinencoding genes in Homosapiens [5]. The number of proteins present in human has been estimated to be as high as 2 million, due to a variety of protein isoforms generated by 
PTMs, alternative splicing or mRNA editing. More than 200 different types of protein modifications have been described, including phosphorylation, glycosylation and proteolytic cleavage. These numbers undoubtedly point to an important role for proteomics. N evertheless, it should be noted that even the most recent and sensitive proteomic studies detect or identify only a fraction of all the expressed proteins, due to the low abundance or extreme biochemical properties of many of the proteins. On the other hand, microarray analysis can detect nearly all transcribed genes. Therefore, the most valuable information will result from combining microarray data with proteomic data.

\section{Development of proteomic techniques}

Concurrent with these new insights, the available techniques to perform proteomic analyses have also undergone major improvements. Although the classical technique of $2 \mathrm{D}$ gel electrophoresis (2D E) already dates from the early 1970s [6], a variety of new techniques have been developed during recent years. These improvements have made it possible to significantly increase the output for qualitative and quantitative proteome analysis. For qualitative proteomic analysis, a major goal was to improve the techniques for subcellular fractionation, since this would increase the total number of proteins that can be visualized from a single cell population or tissue. Second, much attention has been paid to optimize strategies for adequate protein separation. Apart from this, many different techniques have been developed recently for relative or absolute quantification in proteome analyses, as this would enable different biological conditions to be compared (e.g., healthy vs diseased tissues).

$O$ ut of a confusing multitude of presently existing proteomic techniques, two major approaches exist for performing proteomic studies, be it either qualitative or quantitative. In the first approach, also called the European way of working, proteins are separated in two dimensions using sodium dodecyl sulfate (SD S) polyacrylamide gel electrophoresis (PAGE). They can be visualized by a wide variety of techniques (further described below) and subsequently identified using mass spectrometry (M S) or, although less common these days, Edman degradation.

In the second approach, M S-based proteomics, proteins are not separated in gel, but in liquid. High-performance (H P) liquid chromatography (LC) is used to separate proteins, or more often, peptides resulting from their enzymatic digestion, in one or more dimensions using column-based techniques. The resulting separated peptides and/or proteins are analyzed and sequenced using MS. This approach is also called the American way, because it is more often used in the USA.

Although some overlapping techniques between the gel- and MS-based proteomic approaches exist, a clear distinction between the two can be made [7,8]. This review will first focus on the different existing and new methodologies presently used for proteomics, including both gel- and non-gel-based proteomics, and second, concentrate on their applications for deciphering the molecular mechanisms involved in T 1D .

\section{Proteomic techniques}

\section{Gel-based proteomic techniques: an introduction}

Electrophoresis as a tool for separating proteins dates from the 1960s. At that time, gel-based separation of proteins was al ready performed in 2D. These early protocols made use of gel rods poured in glass tubes for separation in the first dimension, and acrylamide gels for second dimension separation [9]. These gel rods were found to have poor handling and reproducibility capacities. O nly 10 years later, with major enhancements made in the protocol, it became possible to separate thousands of proteins in a reproducible manner $[10,11]$. In the first dimension, proteins are separated according to their isoelectric point (pl). This implies that their natural charge has to be preserved, which compromises the use of SDS as a solubilizing agent. Instead, high concentrations of urea are used (7-9 M), most often in combination with thiourea (2 M ). This first dimension is executed in polyacrylamide gels with an internal $\mathrm{pH}$ gradient, made by small molecules, so-called ampholines. A major breakthrough was achieved by the development of immobilized $\mathrm{pH}$ gradient gel (IPG) strips [12]. In this system, a series of buffering acrylamide derivates, termed immobilines, are copolymerized with the acrylamide matrix. Extremely stable pH gradients are generated in this manner, enabling steady-state isoelectric focusing (IEF) with great reproducibility (FIGURE 1).

For the second dimension separation, gradient or nongradient acrylamide gels are used. These enable the separation of proteins according to their molecular size, which implicates that the proteins have to be denatured and unfolded completely. In addition, their net charge has to be equalized. This is performed by making use of the strong negative molecule SD S. U sing large format first dimension gel strips (up to $24 \mathrm{~cm}$ ) and gels (e.g., $24 \times 20 \mathrm{~cm}$ ), up to 1000-2000 proteins are separated routinely (FIGURE 1).

A major advantage of the gel-based separation of proteins compared with the liquid-based separation (seenext section), is its ability to visualize proteins that have undergone a PT M or mutation. These appear as spot trains in the horizontal and/or vertical axis of the gel (e.g., phosphorylation, glycosylation and limited proteolysis or point mutations). Another advantage is the high amount of proteins that can be separated. D ue to the commercial availability of a whole range of different $\mathrm{pH}$ strips for first dimension separation, this technique has become the most powerful existing separation technique for proteins. Using a combination of separate narrow-range $\mathrm{pH}$ strips, more than 10,000 proteins can be separated from a single tissue or cell extract. For example, a study of the mouse proteome using prefractionation of proteins and organ-specific samples yielded an estimated 27,752 unique protein spots in total [13]. This is much more than can be obtained by any currently available non-gel-based separation technique. In addition to this, major efforts have been undertaken to further improve the separation capabilities of this technique, by optimizing different prefractionation techniques. The isolation of different subcellular fractions can significantly improve the separation and visualization capacities of the proteins on a 2D gel. Also, special optimized protocols for the separation and visualization of specific subsets of the proteome are being designed [14-16]. 

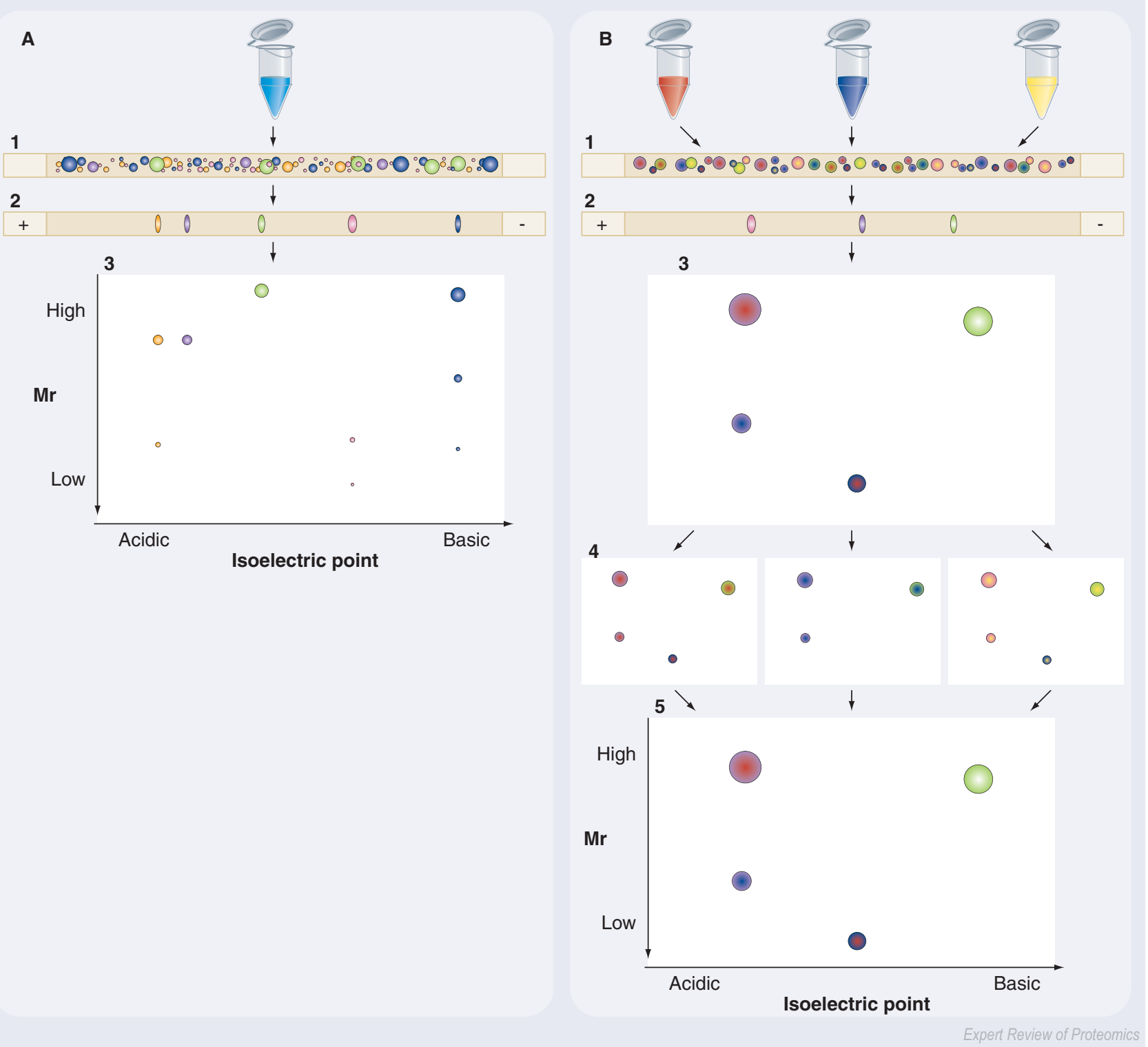

Figure 1. (A) General overview of 2D electrophoresis. (A1) A protein sample is applied on the first dimension strip (usually ranging between 50 and $500 \mu \mathrm{g}$ of protein). (A2) After applying an electric current protocol, which depends on the strip type (pH range and company), proteins migrate towards their isoelectric point. The proteins will be equalized in charge and completely denatured preceding the second dimension. After finishing the first dimension, the strip is placed on top of an sodium dodecyl sulfate (SDS) polyacrylamide gel. (A3) Once again, current is applied, enabling the proteins to migrate into and through the SDS polyacrylamide gel. The gel can subsequently be stained. In order to perform a differential analysis, multiple separate gels must be run using this approach. (B) An overview of the 2D differential in-gel electrophoresis technology. A total of $50 \mu \mathrm{g}$ of protein from Sample 1 (e.g., control sample) is labeled with cyanine (Cy)3 (red), and $50 \mu \mathrm{g}$ of protein from Sample 2 (e.g., treated sample) is labeled with Cy5 (blue). The internal standard (a pool of Samples 1 and 2) with equal protein amount is labeled with Cy2 (yellow). (B1\&2) The three samples are then pooled and run on the same 1D strip and applied to the second dimension (B3). (B4) After completion of the second dimension, the gel is scanned with the three different excitation wavelengths of the fluorescent dyes. (B5) An overlay picture is generated and statistical analysis performed to reveal differences in protein abundance. Proteins of interest (e.g., differential spots from one of the two approaches) will be cut out of the gel and enzymatically digested. Resulting peptides will be subjected to mass spectrometry for protein identification.

U pon gel-based protein separation, each spot on the 2D gel will ideally contain one individual protein (rarely two or more, due to identical or almost identical properties). Subsequently, the protein spots of interest will have to be identified. For this purpose, the spots are cut out of the gel, either manually or using a robotic spot-picker, and the proteins are enzymatically digested inside the gel piece (e.g., by trypsinization). If the genome sequence of the species under investigation is available, the most commonly used approach for identification of 2D protein spots is peptide-mass fingerprinting. In this case, the resulting peptides are extracted and subjected to matrix-assisted laser desorption/ionization (M ALDI) time-of-flight (TOF) M S analysis. The peptide masses acquired by the MALDI-TOF instrument are matched against the list of calculated peptide 
masses from each entry in the database (e.g., using the MASCOT ${ }^{\circledR}$ software), resulting in the identification of the digested protein. In case no genomic database is available or no significant hit is made, sequence information must be acquired. This can be obtained using a MALDI tandem TOF (TOF/TOF) instrument or another mass spectrometer capable of generating sequence information; for example, a quadrupole (q)TOF mass spectrometer. Sequence information can also be obtained by Edman degradation; but this technique requires a high amount of protein or peptide, which is most often not available from a single 2D E protein spot.

\section{Gel-based proteomic techniques: recent developments}

During the last decade, major advances have been made to improve both first- and second-dimension protocols. As a result, prefractionation became more and more important in an attempt to further enhance the amount of proteins to be separated from a single tissue or cell lysate sample [17-19]. C ommercial companies came into the picture, who were willing to devote a large or small part of their efforts to improve on hardware and software for proteomic analysis. As 2DE became widely used and accepted, the technique has undergone extensive standardization (e.g., the length of IPG strips), making it possible to combine supplies from different companies. Also, the available equipment has improved substantially and has become more user-friendly.

Since proteins have a wide dynamic range in abundance, spot visualization has always been one of the major problems in $2 \mathrm{DE}$. I deally, visualization techniques should both be very sensitive and should provide a broad dynamic range for quantification. When prelabeling proteins, the method should not alter (or alter in a reproducible manner) the charge state or mass of the proteins. In this part, a description of the most commonly used as well as latest labeling and staining technologies for $2 \mathrm{DE}$ will be given. Their most important characteristics are summarized in TABLE 1. Classical stains, such as silver, Coomassie Blue or reverse staining, have already been extensively described in other recent review articles [20,21].
Radioactive labeling of proteins by incorporation of radioisotopes is already a very old technique, used for instance by 0 'Farrell [10]. An advantage of this labeling technique is that the charge state or mass of the proteins is not altered. Although many different protocols exist, the most recently developed method uses the radioactive isotopes ${ }^{125}$ and ${ }^{131}$. Advantages of this technique are:

- O utstanding sensitivity (some sources have reported detection limits as low as $10^{-3} \mathrm{ng}$ )

- Broad linear dynamic range of up to 8 orders of magnitude

- Possibility to conduct relative quantitative analyses by combining ${ }^{125}$ and ${ }^{131} \mid$ in a single gel

On the other hand, disadvantages related to this technique are the high costs associated with waste handling and the fact that the technique is restricted to cell culture experiments.

A more recently developed system, especially suitable for quantitative purposes, is the 2D differential in-gel electrophoresis (DIGE) system, which makes use of cyanine (Cy) dyes [22,23]. These dyes bind to the $\varepsilon$-lysine groups of proteins. They carry a positive charge that compensates for the loss of charge caused by binding to the lysyl residue. Today, three dyes are commercially available: Cy3, Cy5 and Cy2 (GE H ealthcare, Uppsala, Sweden). This system makes a real quantitative approach possible and tackles some very important issues in 2DE [24]. First, as these dyes are equalized in mass, they enable different samples to be labeled with a different dye and run on a single gel (e.g., control vs diseased). Evidently, this opens possibilities for analyzing changes in protein expression profiles, with a much better statistical certitude compared with the classical method of silver- or Coomassie Bluestained gels, which is performed by analysis of the two samples run on separate gels. In addition, smaller changes in protein expression can be detected with high statistical significance. The recent development of a third fluorescent dye (Cy2) permits the application of an internal standard in each replicate gel. This internal standard, usually a mixture from the control and treated sample, is used to minimize gel-to-gel variation, thus further improving the statistical

Table 1. Overview of different common visualization methods for 2D gel electrophoresis and their major characteristics.

\begin{tabular}{lllll}
\hline Visualization method & $\begin{array}{l}\text { Lowest amount } \\
\text { detectable (ng) }\end{array}$ & $\begin{array}{l}\text { Linear dynamic } \\
\text { range }\end{array}$ & Differential display & Quantification \\
\hline Silver stain & 0.1 & $60-100$ fold & Two gels/graphic manipulations & Relative \\
Negative imidazole zinc staining & 1.4 & $10-100 \mathrm{ng}\left(10^{1}\right)$ & Two gels/graphic manipulations & Relative \\
SYPRO Ruby & 0.5 & $10^{3}$ & Two gels/graphic manipulations & Relative \\
Deep purple & 0.06 & $10^{4}$ & Two gels/graphic manipulations & Relative \\
Colloidal Coomassie Brilliant Blue & 15 & $30-250 \mathrm{ng}$ & Two gels/graphic manipulations & Relative \\
Cy-dyes (minimal labeling) & 1 & $10^{4}$ & One gel & Relative \\
Cy-dyes (maximal labeling) & 0.1 & $10^{4}$ & One gel, two samples & Relative \\
ProteoTope platform ${ }^{125}{ }^{131}$ | & $10^{-3}$ & $10^{8}$ & One gel, two samples, phosphorylation & Absolute and relative \\
\hline
\end{tabular}


relevance of the detected protein abundance differences. The original protocol is a minimal labeling approach, whereby only $3-5 \%$ of the proteins receive a Cy dye. As a result, only one lysine residue per protein is tagged, preventing the formation of vertical trains of spots on the 2D gel, which would result from the increased mass added by binding of the dye. If more lysine residues per protein were tagged, this could al so impede trypsin action on the blocked residues, thus providing difficulties for subsequent identification. It should be noted that, in the minimal labeling procedure, a shift is encountered in the low-molecular-weight region of the gel, since the bulk of the protein (the unlabeled portion) can be as far as one spot diameter lower than the labeled portion [25]. This will necessitate post-staining of the 2D gels to visualize the bulk of unlabeled protein prior to cutting out the protein spots of interest for identification. The sensitivity of the 2D-DIGE method is very high, compared with Coomassie- or silver-staining methods, thus enabling protein detection as low as $1 \mathrm{ng}$.

To further increase the sensitivity of protein detection, an analogous method has been developed (GE H ealthcare) that uses saturation labeling. In this case, a similar set of dyes is used (Cy3 and Cy5 only), but they react on the cysteine residues of the proteins. As little as $100 \mathrm{pg}$ of protein per spot can be detected using this technique. This opens the possibility to generate quantitative gel-based proteomic studies on very scarce samples; for example, fluorescent-activated cell sortingpurified cells or laser-capture dissection material. A first disadvantage for this method is that the $\mathrm{Cy}$ dyes are hydrophobic, and thus saturation labeling renders the proteins much less resolvable. Up to $40 \%$ of the protein population can precipitate during the labeling reaction, which accounts mostly for the higher molecular weight proteins [25]. Second, proteins that do not contain a cysteine residue will not be detected. Third, the method necessitates the availability of an expensive scanner (e.g., Typhoon ${ }^{\mathrm{TM}} 9400$ series) for fluorescent imaging. The latter will also be needed for the minimal labeling protocol. Recently, new and cheaper charge-coupled device camera-based equipments have become available (e.g., proXPRESS ${ }^{T M}$ from PerkinElmer, Inc. or Ettan DIGE Imager from GE Healthcare), which enable a considerable reduction in running costs.

Apart from the classical staining methods such as silver and Coomassie Blue, two new and widely used fluorescent stains have recently been introduced for total protein post-staining of 2D gels: D eep Purple ${ }^{\mathrm{TM}}$ (GE Healthcare) [26] and SYPRO ${ }^{\circledR}$ Ruby (M olecular Probes, Inc., CA, US) [27]. They both have a sensitivity comparable to the best silver-staining methods, but they yield a much higher dynamic range.

Recently, specific staining methods have been developed for the selective staining of two major PTM s, phosphorylation and glycosylation; Pro- ${ }^{\circledR}$ Diamond and Pro-Q Emerald, respectively (M olecular Probes, Inc.). These two stains open interesting opportunities for multiplexed staining, enabling the visualization of all phosphorylated or glycosylated proteins within a 2D gel $[28,29]$. H owever, one study found some minor differences between the images from a Pro-Q D iamondstained gel and the same protein sample labeled with radioactive ${ }^{32} \mathrm{P}$. This could be due to the low turnover rate of some phosphorylated proteins [30].

Finally, another new and promising technique is blue native electrophoresis. Blue native electrophoresis is also a type of 2DE [31-33]. Protein complexes are separated in a first dimension according to their molecular mass. The second dimension is performed under denaturing conditions, enabling the complex to fall apart in its individual subunits. These subunits are separated on the basis of their individual molecular masses.

\section{Non-gel-based proteomic techniques: an introduction}

From a historical point of view, the M S-based approach has been introduced more recently than the gel-based approach. A major breakthrough came with the invention of the so-called soft ionization methods, namely M ALDI [34] and electrospray ionization (ESI) [35] in the late 1980s. U sing this sophisticated equipment, larger biomolecules could be analyzed without breaking them apart. The ESI method is based on ionization of the molecules out of a solution, and is therefore most often coupled to a liquid-based separation device (e.g., nano-LC [36] or capillary electrophoresis [CE] [8]). $0 \mathrm{n}$ the other hand, in the MALDI method, a dry crystalline matrix is mixed with the analytes. A laser pulse is then used to convert the peptides or proteins in a gaseous and ionized state.

In the gel-based approach, protein separation and identification are performed in two well-separated steps. Contrary to this, identification readily follows separation in the M S-based approach. The separation step is often directly coupled to the mass spectrometer, which not only measures, but al so identifies, the proteins (usually after their cleavage into peptides). A wide variety of elegant separation techniques have been designed, a number of which can be considered as a link between gel- and M S-based proteomics $[7,8]$. The most popularly used technique is the chromatographic separation of a peptide mixture, which was generated by tryptic digestion of the protein sample, in two dimensions (strong cation exchange as the first and reverse phase as the second dimension) (FIGURE 2) [37-39]. This method has some distinct advantages over classical gel separation. Since the analysis is performed on a pool of tryptic digested peptides, proteins of all sizes can be identified. In this regard, identifications of proteins with a molecular weight over $500,000 \mathrm{Da}$ have been reported, which would not be possible using gelbased techniques [40]. Another advantage is the possibility to identify low-abundance proteins as well as proteins with extreme pls, which could not be readily visualized or identified on $2 \mathrm{D}$ gels.

On the other hand, despite the ever-increasing technical improvements, the M S-based technique also has some disadvantages as compared with gel-based techniques. First, gelbased assays enable the detection of a greater number of proteins. No study could separate as many proteins using 2D -LC compared with $2 \mathrm{DE}$. Second, it should be noted that many identifications are made on a single peptide only, and thus the 
results must be interpreted with some caution. Third, since many of the peptides resulting from a single protein are very often missed in the fragmentation step, 2D-LC coupled to qTOF (one of the most used combinations) has a poor capacity for identifying PT M s. These modifications, which will not be detected at all using the current method, are often critical for the function of a protein, and may be the only difference in a specific experimental set-up (for instance comparing a control with a diseased state). Finally, already in the early years of MS, one problem was the fact that apparently not all peptides ionized in a similar way. This was troublesome for the quantification of proteins at first. Different recent developments have tackled this problem; for example, isobaric mass tags for relative and absolute quantitation (iTRAQ ${ }^{\mathrm{TM}}$ ) [41], stable isotope labeling by amino acids in cell culture (SILAC) [42], absolute quantification (AQU A) [43], isotope-coded affinity tag (ICAT) [44] and solid-phase isotope tagging [45]. These developments resulted in a major breakthrough in the field of M S-based quantitative proteomics.

\section{Quantitative mass spectrometry-based analyses}

O ne of the most important improvements in M S-based proteomics, apart from the ever-continuing upgrading of hardware and software, are the advances made in quantitative M S-based proteomics and the possibility to investigate PT M s.

The involvement of MS for the detection of peptides requires the molecules to be converted in an ionized state and, subsequently, be transferred into the gas-phase. This ionization process

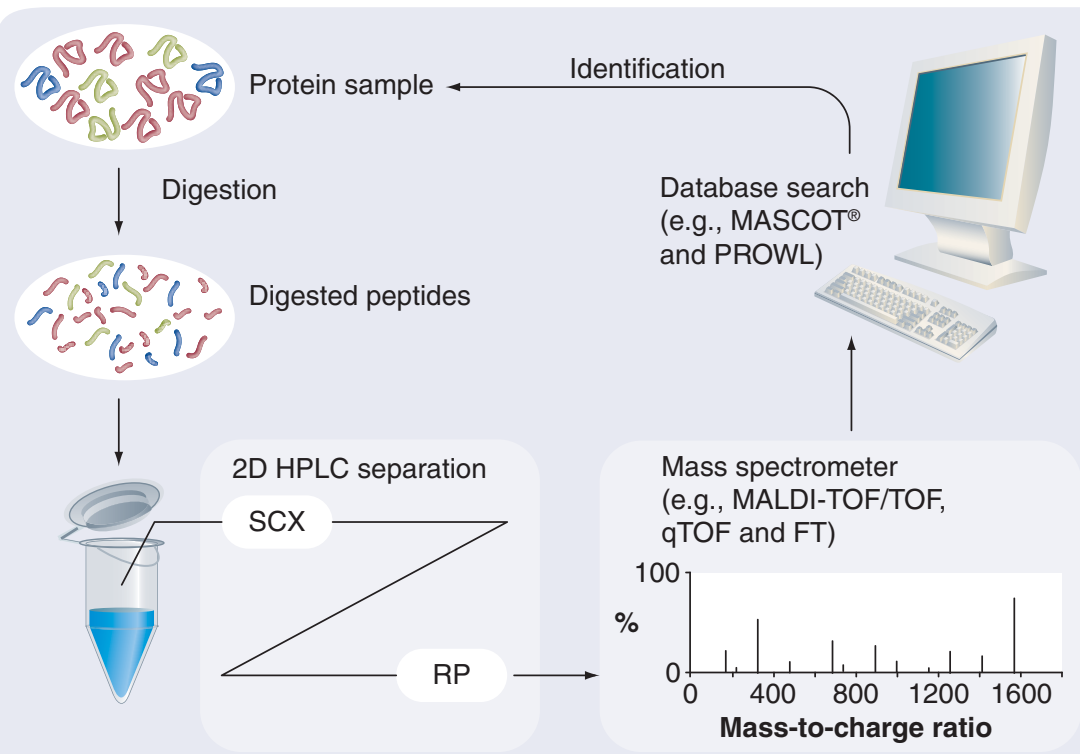

Figure 2. Classical 2D liquid chromatography mass spectrometry. A cell lysate or fraction is digested with an enzyme (e.g., trypsin or chymotrypsin). The resulting peptides are separated in two dimensions with a SCX column and a RP column. The separated peptides are analyzed either online (electrospray ionization) or off-line (MALDI ionization) with a mass spectrometer. The fragmentation spectra are submitted for identification to MASCOT ${ }^{\circ}$ or other online or in-house search algorithms.

FT: Fourier transform; HPLC: High-perfomance liquid chromatography; MALDI: Matrix-assisted laser desorption/ionization; RP: Reverse phase; SCX: Strong cation exchange; TOF/TOF: Tandem time- of-flight. is dependent on the physicochemical properties of the peptides (ionization efficiency) as well as on the presence of other components (such as buffers or solvents) in the sample mixture (suppression effects). C onsequently, the intensity of a particular peptide signal is not a simple function of its abundance. Therefore, the ion signals of two different peptides or the signal intensities of the same peptide ion from two independent experiments cannot be compared with each other. In an attempt to enable quantitative analysis, a wide variety of creative solutions to solve this problem have been described. A selected number of these techniques are discussed here.

O ne of the first methods for quantitative proteomic analysis for complex mixtures of proteins is the ICAT method, which was first described by Gygi and coworkers [44]. This method makes use of an ICAT reagent, which consists of a thiol-specific reactive group, a linker with eight deuterium atoms for the heavy reagent (opposed to normal hydrogen for the light reagent) and a biotin affinity tag. In the experimental protocol, the two protein samples to be compared are differentially derivatized with either the isotopically light or heavy chain of the ICAT reagent. This derivatization occurs at the side chains of cysteinyl residues of the proteins. Subsequently, the two labeled protein samples are pooled and enzymatically digested. The cysteine-containing peptides are isolated by avidin affinity chromatography and separated with nano-LC prior to tandem M S (M S/M S). A mass difference of $8 \mathrm{Da}$ (for singly charged peptides) or $4 \mathrm{Da}$ (for doubly charged ions) between ion pairs is observed, resulting in two separate peaks for each of the differentially labeled proteins to be compared between the two samples. This enables quantification of the peptides in the MS mode. The ratios between the intensities of the lower and upper mass components of these pairs of peaks provide a quantitative measure of the relative abundance of the peptides in the original sample pools. Although ICAT is a very interesting technique, a disadvantage is that only proteins that contain a cysteine residue will be detected. Also of note, the site-specific tagging group of the ICAT reagent bears the possibility for an alternative chemical engineering, and thus the isotopes and the attached affinity tags can be used for selective isolation and analysis of specifically functional groups or protein classes. A number of these isotope-tagging chemistries have been developed specific for sulfhydryl groups [45], amino groups [46], active sites for serine [47] and cysteine hydrolases [48], phosphate ester groups [49], and for $\mathrm{N}$-linked carbohydrates [50]. Finally, a combination of 2DE and ICAT has been described, but this appears to be a rather marginal application [7]. 
Concurrent with the development of the ICAT method, another group reported an alternative method for quantitative M S-based analysis. In this method, proteins are not labeled after their extraction, as in the ICAT method, but they are labeled during culturing of the cells. This is performed by the use of an enriched culture medium with ${ }^{15} \mathrm{~N}$ for metabolic labeling of the proteins [51]. After culturing, the two samples (labeled and nonlabeled) are pooled, and proteins are separated and purified with electrophoresis before single spots can be digested and analyzed. A major advantage, as compared with the ICAT method, is that all proteins will be labeled. On the other hand, this method also has some distinct disadvantages. Indeed, the method is only applicable for in vitro cultured cells, and not for labeling of tissue samples. Furthermore, since each peptide may contain a different amount of incorporated ${ }^{15} \mathrm{~N}$, the procedure proved to be rather difficult to automate. N evertheless, metabolic labeling has proved to be a useful technique for cell cultures, and many variations on this technique have been made to date [52]. O ne of these is SILAC, a protocol specially developed for investigations on mammalian cells [42]. In this case, deuterium-labeled leucine is incorporated into the proteins during cell culturing. M ore recently, other amino acids have also been reported as useful in this assay $[53,54]$.

A third method for a quantitative analysis of protein mixtures is an isotopic labeling approach using trypsin and ${ }^{18} \mathrm{O}$-enriched water. In this protocol, ${ }^{18} \mathrm{O}$ is incorporated into the peptides through the enzymatic incorporation of oxygen in the $\mathrm{C}$-terminal end of the peptide during the digestion procedure $[55,56]$. As for ICAT, this method can be used for any protein extract (i.e., cells, tissues or tissue biopsies). A disadvantage is the mass difference of only $2 \mathrm{D}$ a, resulting in overlapping ion envelopes in the higher mass region.

A fourth way of conducting quantitative experiments in an M S-based approach is the use of synthetic peptides as isotopelabeled internal standards [57]. Contrary to the three approaches described above, which only enable relative quantification, this methodology was developed for absolute quantification of proteins. Gygi and coworkers have further improved this method by developing the AQUA strategy [43]. Stable isotopelabeled synthetic peptides are introduced as an internal standard to a protein sample during proteolytic digestion. This was found to be a useful method for the quantitative analysis of proteins as well as some PTMs. However, the method is not suited for large-scale analyses.

Recently, a new and very promising technique, iTRAQ, has been added to the number of M S-based relative quantitative proteomic techniques [41]. This method is based on the development of a multiplexed set of isobaric reagents that yield aminederivatized peptides. Each reagent consists of three groups: a reporter, balance and peptide reactive group. The peptide reactive group binds at the $\mathrm{N}$-termini and lysine side chains of peptides, thus linking the iTRAQ reagent isobaric tag to all peptides derived from a tryptic digest of the protein sample. Through combining multiple iT RAQ -labeled digests into one sample mixture, the mass spectrum of the mixture resembles the spectrum of an individual sample (if the same peptides are present). The balance group ensures that every iT RAQ reagentlabeled peptide displays the same mass, whether it is labeled with reagent $114,115,116$ or 117 . D uring the M S/M S step, the reporter group is cleaved from the remainder of the reagent along with the peptide fragmentation. As a result, the reporter groups generate diagnostic ions in the low-mass region between mass-to-charge ratios 114 and 117. Q uantification of the peak areas of these reporter ions is representative for the relative amount of a given peptide in the respective protein sample.

\section{Analysis of post-translational modifications}

PT M s are important biological events. These processing events change the properties of a protein by adding one or more modifying groups to the protein or by proteolytic cleavage of the protein. PT M s can be responsible for the final activity of a protein, its localization or its interaction with other proteins. Also, specific forms of PT M s target proteins for degradation; for example, ubiquitination [58,59]. It has been estimated that almost $50 \%$ of all proteins possess one or more PTM [60]. D espite their apparently important significance, the identification of PTM $\mathrm{s}$ has long been hampered by the lack of suitable methods. The introduction of MS in the field of protein research has set a milestone for the identification of PTM $\mathrm{s}$. $\mathrm{H}$ owever, it is beyond the scope of this article to discuss all the different methodologies for PTM analysis, and the authors recommend the following interesting reviews by some of the renowned researchers in the field [61-63].

\section{Capillary electrophoresis coupled to mass spectrometry \& surface-enhanced laser desorption/ionization}

Although not directly possessing the ability for a quantitative analysis, CE-MS is another fairly new and promising technique. In this approach, polypeptides are separated with gel electrophoresis conducted in a small capillary. The capillary outlet is either directly or indirectly coupled to a mass spectrometer for identification of the polypeptides. An advantage of this technique is the short experimental time for a run compared with classical 2DE and, for this reason, it is more readily applicable for high-throughput clinical studies. A known disadvantage of this approach is the low loading capacity of the capillary column and the difficulties associated with optimization of the CE step with the M S step [8].

Another novel, promising technique is the so-called surfaceenhanced laser desorption/ionization (SELDI) affinity technology. Basically, this is a M S-based proteomic approach with a few similarities to M ALDI-TOF analyses regarding the ionization method and type of mass spectrometer used (TOF tube with detector at the end). The great advantage of this technology is its possible ability to separate a complex sample or to purify a ligand on-target. The laser desorption/ionization target or protein-chip functions as a solid-phase extractor through chemical or biochemical modification of the probe, and could be manipulated into almost any form. The specificity of the affinity probe surface ranges from immobilized transition metals 
to biomolecular interactions specific for DNA, antibodies, receptors, ligands and so on [64-66]. This technology appears very promising for clinical research and biomarker discoveries, and an increasing number of studies have used SELDI in a clinical approach [67-71]. It should be noted that a correct interpretation of the data is crucial for obtaining valuable results [72].

\section{Type 1 diabetes}

T1D is an autoimmune disease characterized by T-cell mediated destruction of the insulin-producing $\beta$-cells in the pancreatic islets of Langerhans. Although the exact triggers initiating the disease definitely need further unraveling, it is clear that $\beta$-cell destruction is mediated by the release of cell-destructive molecules, including cytokines (such as interleukin [IL]-1 $\beta$, interferon [IFN ]- $\gamma$ and tumor necrosis factor [T N F ]- $\alpha$ ), granzyme $B$ or perforin, or by direct delivery of cell-death signals [73]. M ost of these signals (when present in high amounts or under appropriate conditions, such as stress situations or inflammation) are reported to induce significant apoptotic $\beta$-cell death (in vitro and in vivo). These dying $\beta$-cells will be taken up by antigenpresenting cells, such as macrophages, which have been described to produce high amounts of inflammatory cytokines upon encounter with dying cells [74], and $\beta$-cell antigens will be made available for the circulating autoreactive T-lymphocytes. From this point of view, $\beta$-cell death can be seen in the context of initiation of autoimmune reactions.

$M$ any studies have been undertaken in an attempt to unravel the pathways involved in this $\beta$-cell destruction, either in insulinproducing cell lines, primary $\beta$-cells or whole islets, upon incubation with a variety of apoptosis-inducing agents (combinations of IFN $-\gamma$ plus IL-1 $\beta$, double-stranded RNA plus IL-1 $\beta$, and Fas plus Fas ligand) [75-78]. The majority of these have been performed at the RNA level by microarray analysis, and suggested that $\beta$-cell death depends on the aberrant activation of a complex network of transcription factors and effector genes. In this regard, one major apoptosis-inducing signaling pathway is mediated by the nuclear factor (N F)-кB. Cytokines can activate $\mathrm{NF}-\kappa \mathrm{B}$ in primary human islets, and administration of $\mathrm{N} \mathrm{F- \kappa B-}$ blocking agents protects $\beta$-cells from cytokine-induced cell death and nitric oxide production [79,80]. Besides IL-1 signaling, which activates $N F-\kappa B, I F N-\gamma$ appears to be necessary to fully trigger $\beta$-cell death.

Although to a lesser extent, different studies have also been performed at the protein level in order to unravel the mechanisms involved in $\beta$-cell death, where changes in protein profiles were investigated in insulin-producing cells lines [81], whole islets [82-84] or transplanted islets [85,86]. In these studies, the investigations were mainly performed upon treatment of the cells with IL-1 $\beta$. Although a significant part of the complex picture of protein expression profiles has already been unraveled based on these studies, many questions remain unanswered.

It is not only the islets of Langerhans that have been subject to proteomic studies related to T 1D. For the identification of autoantigens and the importance of their PT M S, M S-based studies have also been undertaken and have aided in our understanding of T-cell recognition of autoantigens $[87,88]$. In a different area of research, proteomics has actively contributed to the understanding and diagnosis of T 1D -related pathologies. In an attempt to identify biomarkers for diabetic nephropathy, proteomic analysis of urinary samples has been undertaken [89].

\section{Studies in rat models}

Although some early studies al ready used 2DE for deciphering mechanisms involved in the pathogenesis of T1D [90], a real breakthrough came much later, which, not surprisingly, was concurrent with the development of more sophisticated MS equipment, since this enabled a much more efficient identification of protein spots. In this regard, extensive research has been performed on rat islets of Langerhans. M ost of these studies have been performed by $N$ erup and coworkers. In all their studies, they made use of $2 D E$, in which protein samples were incorporated with $\left[{ }^{35} \mathrm{~S}-\mathrm{M}\right.$ et], which enabled quantitative measurements. For first-dimension separations, they used IEF strips for the $\mathrm{pH}$ 3.5-7 range in combination with nonequilibrium $\mathrm{pH}$ gradient gel electrophoresis (N EPH GE) strips for the basic $\mathrm{pH}$ range (pH 6.5-10.5). Different studies were undertaken to investigate the effects of IL-1 $\beta$ on islet protein expression changes from Wistar-Furth rat islets [91-93]; as well as from BB-diabetes prone (DP) islets in comparison with BB-diabetes resistant rats $[94,86]$. The group found 82 spots demonstrating changes in expression in BB-D P rats after exposure of the islets to IL-1 $\beta$. A total of 45 of these spots could be identified and were classified into one of the following groups:

- Energy transduction and redox potentials

- Glycolytic and K rebs cycle enzymes

- Protein synthesis, chaperoning and folding

- Signal transduction, regulation, differentiation and apoptosis

- Cellular defense

However, they failed to pick up some already well-known cytokine-modified proteins, such as inducible nitric oxide synthase (iNOS), insulin and manganese superoxide dismutase. iN O S has a pl of 6.89 and a molecular weight of $130.6 \mathrm{kDa}$, and thus appears at the borders of the gels used by this group. In this area, resolution and reproducibility of the gels are inaccurate [85]. Through the use of other first-dimension strips with different $\mathrm{pH}$ ranges, the resolution in this area could be improved. As for insulin, proteins with molecular masses smaller than $12 \mathrm{kDa}$ are not detected using $2 \mathrm{DE}$ [81]. Again, this points to a limitation of $2 D E$ analyses (i.e., that only a limited percentage of the total protein content can be visualized as compared with microarray analyses). Furthermore, effects of low-protein diet on intra-uterine environment and development of $\beta$-cells and islets through intra-uterine gene programming have been investigated by the same group [95]. Finally, a large in vivo study has been performed where they investigated the protein expression changes in syngeneic islets from newborns transplanted under the kidney capsule of 30-day old BB rats (7 weeks before disease onset) [85]. This study confirmed 60 protein spots out of the 82 previously 
identified proteins that changed expression by IL-1 $\beta$ in an in vitro islet cell culture system (BB-D P islets). These were also shown to be important for diabetes development in vivo. This revealed a complex pattern of protein expression changes responsible for diabetes development $[96,97]$.

\section{Studies in mouse models}

W hile investigations on rat islets have been the subject of many publications, studies in mouse models have been very limited. Although no studies investigating cytokine-induced apoptosis of pancreatic islets are available, different proteomic studies of interest have been published in this field. A first detailed protein 2D reference gel map has been published by Sanchez and coworkers for normal mouse islets [98], and published on the mouse SW ISS 2D -PAGE [201], visualizing 2528 different spots in the $\mathrm{pH}$ range 3.5-10. Although not directly related to T 1D studies, this 2D map is a very valuable start for further investigations. In this 2DE reference map, whole pancreatic islets isolated from 8-week old C 57BI/6J females were used. A total of 44 protein spots were identified by either gel matching, Edman degradation, peptide-mass fingerprinting (M ALDI-TOF-M S) and/or peptide fragment sequencing (qTO F-M S). This reference map can be useful for scientists using similar 2DE protocols for comparison of their images. Following two more recent studies, 76 new protein identities were added to this first reference map $[99,100]$. The latter study demonstrated that many proteins implicated in Alzheimer's disease are highly expressed in normal pancreatic islets.

Finally, very recently, 28 new protein entries were added to the mouse islet reference map [101]. In this study, the effect of 11-mM glucose on protein changes in mouse islets was investigated compared with freshly isolated islets. O ut of a total of 1074 protein spots, 379 spots were differentially expressed. A total of 124 of these corresponded to 77 different proteins. By comparison of silver-stained 2D gels, 379 protein spots were morethan twofold changed in expression upon incubation with 11-mM glucose. These included proteins involved in enhanced insulin synthesis, granular mobilization and maturation and increased stress response [101].

Recently, a first study investigating protein expression changes in a knockout mouse model has been published, which compares changes in protein expression in islets from the $\alpha_{2}$-adrenergic receptor. Although more related to mechanisms taking place in Type 2 diabetes, the technical set-up may also be of interest for studies in T1D. This study made use of the 2D DIGE technique, identifying significant changes in protein spots of as low as 1.2-fold. In the pH range 4-7, approximately 1500 spots were detected, 25 of which were differentially expressed compared with control islets. Of interest, the findings identified a role for the $\alpha_{2}$-adrenergic receptor in suppressing insulin release upon glucose stimulation. Proteins involved in insulin processing, biosynthesis and/or regulated secretory release were identified as being regulated in this system [84]. Apart from proteomic studies on pancreatic islets, a different study analyzed the proteome profile of mouse kidneys, with the main goal to identify alterations in protein expression associated with diabetic nephropathy, one of the well-known complications associated with T1D. Again, this study used 2DE, reporting a first protein reference map for mouse kidneys, which consisted of 300 visualized protein spots in the pH 3-10 range, as analyzed by SYPRO Ruby staining. Of these, 41 spots were shown to be differentially expressed in the OVE-26 transgenic mouse model, a model for early-onset T ID nephropathy. Proteins of importance in diabetic nephropathy, as concluded from this study, were proteases, protease inhibitors, apoptosisassociated proteins, regulators for oxidative tolerance, calciumbinding proteins, transport regulators, cell signaling proteins and smooth muscle contractile elements. Further evidence was provided for an important role for elastin, an extracellular matrix protein, in diabetic nephropathy [102].

\section{Studies on human material}

Although proteomic studies on human tissues would be very helpful in studying the etiology of T 1D, no proteomic studies on $\beta$-cell destruction and the development of TID are currently available from human sample material. An early study used NEPH GE on rod gels to investigate a specific marker for T 1D [90]. A more extensive reference map describing the whole protein expression profile in human pancreata has been recently described, and is a good starting point for further investigations. In this study, a reference 2D map was published, with 302 identified proteins [103]. M ore recently, another group published a detailed 2DE map of purified human pancreatic islets [104]. $\mathrm{H}$ ere, a total of 744 proteins were detected between the $\mathrm{pH}$ range 4-10, of which 130 were identified by M ALDI-TOF and annotated to 66 different proteins. M ost of these proteins have been similarly identified in mouse islets, although 13 protein identifications resulted in new entries $[98,100]$.

For a totally different application, although also related to T ID studies, SELDI-TOF-M S has been used to detect autoantibodies against glial fibrillary acidic protein, in newly diagnosed diabetic children with T1D [67]. This suggested that immune mediated $\beta$-cell destruction may be mediated by aberrant targeting of peri-islet Schwann cells. Also using TO F-M S, peptide epitopes from naturally processed proinsulin were identified. These were further used to assess the nature of autoreactive T-cells in T1D [87]. A specific PTM of proinsulin (i.e., the formation of a vicinal disulfide bond between adjacent cysteine residues at $A 6$ and $A 7$ ) was recently shown to be specifically recognized by $\mathrm{CD} 4^{+} \mathrm{T}$-cell clones isolated from blood of T 1D patients, but not from controls. This was determined by M ALDI-qTO F-M S/M S analysis, seen as a loss of $2 \mathrm{D}$ a at the adjacent A6-A7 cysteines [88]. Interestingly, this study revealed for the first time that a PT M on proinsulin is required for T-cell recognition of the insulin A chain in T 1D.

In the field of clinical nephrology, great advances are being made in developing high-throughput assays to screen urine samples for early detection of diabetic nephropathy. A novel proteomic approach, CE-M S, has been described to enable a high-throughput analysis of polypeptides and proteins from 
urine samples. U sing this method, more than 1000 polypeptides, ranging from $800 \mathrm{D}$ a to $66.5 \mathrm{kD}$ a could be separated, 54 of which were specific for T1D patients (i.e., absent in normal control samples). In addition, 88 polypeptides were specific for diabetic nephropathy [105]. This method may enable an earlier and more accurate detection of individuals at high risk for developing diabetic nephropathy. The same method has resulted in the identification of 113 polypeptides, specific for a diabetic renal damage pattern, which is typical for diabetic nephropathy associated with T2D [106].

\section{Expert commentary $\&$ five-year view}

Although proteomics has definitely taken an important place in many research and clinical laboratories during the last couple of years, technical improvements on the technique will be important to further optimize the technique. In this regard, for the further development of gel- or M S-based proteomics, prefractionation techniques will certainly gain in importance. Indeed, further separation and identification power without losing precious sample appears to be a matter of improving fractionation methodologies. The IEF step in 2DE is especially prone to a considerable loss of sample material. D epending on the pH range of the first dimension IEF strip (e.g., narrow IPG or zoom strips), up to $50 \%$ of the sample can be lost. Different roads are al ready being explored, such as IEF for peptides prior to M S-based proteomics [107], different prefractionation methods for 2DE, such as H PLC fractionation, prior to IEF [18], a fractionation step in-gel prior to IEF [17], or subcellular prefractionation [19]. Another way to avoid sample losses is the use of very long IPG strips with a very broad $\mathrm{pH}$ range. Pilot studies have been made using either one long strip [108] or the daisychain method $[109,110]$. The analysis of PTM $s$ is also of evergrowing importance, and subject of many technical and experimental improvements [61]. Understanding the proteome in terms of how organisms live and respond to different conditions requires a variety of methods for analyzing the changes in proteins themselves. As discussed above, each of the described methods has its own advantages and drawbacks. It is evident that the gel- or M S-based approaches by themselves cannot provide us with all the answers needed, but a combinatorial use of different complementary methods should significantly increase the outcome of the results, and offer a more complete view on the total proteome of a cell or tissue state.
Here, two new developments will be discussed, which the authors believe will gain much attention in the coming years. The first one, peptidomics (the analysis of all peptides expressed in a cell or tissue), is a logical next step in the exploration of the proteome of an organism. At present, a M ED LINE search for the term 'peptidomics' results in only 45 hits [202]; the most interesting of which are [111-114]. $M$ ass spectrometers will not only be used to analyze peptides derived from enzymatic digests of proteins, but also for the identification and quantification of neuropeptides, antimicrobial peptides and signaling peptides [115]. To date, the main applications of imaging MS were in biomedical research. This promising new development is a growing field, and already has some applications in cancer research [116,117] and pharmaceutical localization [118]. Tissue imaging and profiling also hold great promise for fundamental research, as better software and M S protocols are being devised [119,120].

In the field of T 1D -related fundamental research, a comprehensive amount of work has been performed investigating the effects of IL-1 $\beta$ on rat islets. These studies have greatly aided in our understanding of the pathways involved in $\beta$-cell death. H owever, to further complete this picture, data from cytokineinduced islets form mice and humans would be very interesting. In addition, the mechanisms involved could be further completed by investigating effects of other $\beta$-cell death-inducing agents, such as combinations of IL $-1 \beta$ with IFN $-\gamma$ and T N F- $\alpha$, double-stranded RNA with IL-1 $\beta$ or Fas and Fas ligand. In this regard, the 2D reference maps of normal mouse and human islets are an interesting starting point for further analysis. In addition, proteomic investigations of mouse islets will enable the analysis of a variety of available transgenic or knockout mouse models, for studying different pathways involved in $\beta$-cell death. During the coming years, it is to be expected that the proteomic analysis of these available models will greatly aid in a better understanding of the mechanisms involved in $\beta$-cell death. $N$ ext to this, with the major improvements in the field of peptidomics, it is again to be expected that new findings will contribute to a further understanding of mechanisms leading to $\beta$-cell death. In view of more clinical applications, proteomic analyses could significantly contribute in our understanding of the mechanisms of promising new therapeutic agents, as well as in the discovery of biomarkers for this autoimmune disease or its associated complications, such

\section{Key issues}

- During the last decade a major breakthrough in the field of proteomics, both in fundamental and clinical research, has been achieved.

- In general, two major fields for protein separation in proteomic research can be identified: gel- and MS- based proteomics.

- Although some studies have investigated effects of $\beta$-cell death in rat islets, greatly aiding our understanding of cytokine-induced $\beta$-cell death in Type 1 diabetes, no such studies are presently available on mouse and human islets.

- New developments in proteomics, especially for post-translational modifications, and quantitative analysis will be of great aid for the further elucidation of pathways involved in Type 1 diabetes. 
as diabetic nephropathy. In conclusion, the major breakthrough in proteomics, made possible by the improvements in available equipment and the availability of the human genome, will result in a better understanding of T1D, both in fundamental research and in clinical biomarker and treatment development. This will definitely help to further solve the puzzle of this complex disease.

\section{Acknowledgements}

This work was supported by the $C$ atholic U niversity of Leuven (Geconcentreerde Onderzoeksacties; GOA 2004/10), the Flemish Research Foundation (FWO G.0084.02, G.0233.04 and $G .0552 .06$ ) and the $C$ entre of Excellence SymBioSys (Research Council KULeuven EF/05/007). Chantal M athieu has a clinical research fellowship (FW 0 ).

\section{References}

Papers of special note have been highlighted as:

- of interest

-• of considerable interest

1 Wilkins M, Gooley A, W illiams K et al. Towards the protein genome: rapid identification of 2D spots by amino acid analysis. Siena M eeting on 2D

Electrophoresis. Siena, Italy, 35-36 (1994).

-2 O verbergh L, Gysemans C, M athieu C. $Q$ uantification of chemokines by real-time reverse transcriptase PCR: applications in Type 1 diabetes. Expert Rev. M ol. D iagn. 6 , 51-64 (2006)

-3 Anderson L, Seilhamer J. A comparison of selected $\mathrm{mRN} A$ and protein abundances in human liver. Electrophoresis 18, 533-537 (1997).

- $\quad$ First published study proving abundance changes at the mRN A level are not always consistent with abundance changes at the protein level.

4 Gygi SP, Rochon Y, Franza BR, Aebersold R. Correlation between protein and $\mathrm{mRN} A$ abundance in yeast. $\mathrm{M} \mathrm{ol}$. Cell Biol. 19, 1720-1730 (1999).

5 Baltimore D. O ur genome unveiled. N ature 409, 814-816 (2001).

-6 Kaltschmidt E, W ittmann H G . Ribosomal proteins. VII. Two-dimensional polyacrylamide gel electrophoresis for fingerprinting of ribosomal proteins. Anal. Biochem. 36, 401-412 (1970).

7 Smolka M, Zhou H, Aebersold R. $Q$ uantitative protein profiling using two-dimensional gel electrophoresis, isotope-coded affinity tag labeling, and mass spectrometry. M ol. Cell. Proteomics 1 19-29 (2002).

$>$ Stutz $\mathrm{H}$. Advances in the analysis of proteins and peptides by capillary electrophoresis with matrix-assisted laser desorption/ionization and electrospray-mass spectrometry detection. Electrophoresis 26, 1254-1290 (2005).

- Excellent review of the different methodologies in this specific field of proteomic research and a few clinical examples. A complete and comprehensive overview of the capillary chromatography methods used and their advantages as well as disadvantages.
\$ Raymond S, Wang YJ. Preparation and properties of acrylamide gel for use in electrophoresis. Anal. Biochem. 1, 391-396 (1960).

-10 O'Farrell PH. High resolution two-dimensional electrophoresis of proteins. J. Biol. Chem. 250, 4007-4021 (1975).

- The standard work and perhaps most quoted article in the gel-based proteomic field.

-11 Klose J. Protein mapping by combined isoelectric focusing and electrophoresis of mouse tissues. A novel approach to testing for induced point mutations in mammals. H umangenetik 26, 231-243 (1975).

-12 Bjellqvist B, Ek K, Righetti PG et al. I soelectric focusing in immobilized $\mathrm{pH}$ gradients: principle, methodology and some applications. J. Biochem. Biophys. M ethods 6, 317-339 (1982).

13 Klose J. G enotypes and phenotypes. Electrophoresis 20, 643-652 (1999).

-14 Zahedi RP, M eisinger C, Sickmann A. Two-dimensional benzyldimethyl-nhexadecylammonium chloride/SD S-PAGE for membrane proteomics. Proteomics 5 , 3581-3588 (2005).

15 Stegemann J, Ventzki R, Schrodel A, de $M$ arco $A$. Comparative analysis of protein aggregates by blue native electrophoresis and subsequent sodium dodecyl sulfate-polyacrylamide gel electrophoresis in a three-dimensional geometry gel. Proteomics 5, 2002-2009 (2005).

16 M CD onough J, M arban E. O ptimization of IPG strip equilibration for the basic membrane protein $\mathrm{mABC}$ 1. Proteomics 5 , 2892-2895 (2005).

$>17$ Gorg A, Boguth G, Kopf A, Reil G, Parlar H, WeissW. Sample prefractionation 25 with Sephadex isoelectric focusing prior to narrow $\mathrm{pH}$ range two-dimensional gels. Proteomics 2, 1652-1657 (2002).

-18 Van den Bergh G, Clerens S, Vandesande F, Arckens L. Reversed-phase high-performance liquid chromatography prefractionation prior to two-dimensional difference gel electrophoresis and mass spectrometry identifies new differentially expressed proteins between striate cortex of kitten and adult cat. Electrophoresis 24, 1471-1481 (2003).

- $\quad 0$ ne of the more readily useful prefractionation techniques.

19 H anson BJ, Schulenberg B, Patton W F, Capaldi RA. A novel subfractionation approach for mitochondrial proteins: a three-dimensional mitochondrial proteome map. Electrophoresis 22, 950-959 (2001).

20 Gorg A, Weiss W, Dunn MJ. Current two-dimensional electrophoresis technology for proteomics. Proteomics 4 , 3665-3685 (2004).

-. Excellent review by one of the founders of the gel-based proteomic technology. A nice and comprehensible overview for beginners in the field as well as for more experienced scientists.

-21 Westermeier R, M arouga R. Protein detection methods in proteomics research. Biosci. Rep. 25, 19-32 (2005).

22 Unlu M, M organ ME, M inden JS. Difference gel electrophoresis: a single gel method for detecting changes in protein extracts. Electrophoresis 18, 2071-2077 (1997).

- First article about the cyanine dyes as a tool for gel-based quantitative proteomics.

23 Tonge $\mathrm{R}$, Shaw J, M iddleton $\mathrm{B}$ et al. Validation and development of fluorescence two-dimensional differential gel electrophoresis proteomics technology. Proteomics 1 , 377-396 (2001).

-24 Van Den Bergh G, Arckens L. Fluorescent two-dimensional difference gel electrophoresis unveils the potential of gel-based proteomics. Curr. 0 pin. Biotechnol. 15, 38-43 (2004)

Shaw J, Rowlinson R, Nickson J et al. Evaluation of saturation labelling two-dimensional difference gel electrophoresis fluorescent dyes. Proteomics 3, 1181-1195 (2003).

26 Coghlan D R, M ackintosh JA, Karuso P. $M$ echanism of reversible fluorescent staining of protein with epicocconone. Org. Lett. 7, 2401-2404 (2005). 
-27 Berggren KN, Schulenberg B, Lopez M F et al. An improved formulation of SYPRO Ruby protein gel stain: comparison with the original formulation and with a ruthenium II tris (bathophenanthroline disulfonate) formulation. Proteomics 2 , 486-498 (2002).

28 Steinberg TH, Agnew BJ, Ge KR et al. Global quantitative phosphoprotein analysis using multiplexed proteomics technology. Proteomics 3, 1128-1144 (2003).

29 Schulenberg B, Patton W F. Combining microscale solution-phase isoelectric focusing with multiplexed proteomics dye staining to analyze protein post-translational modifications. Electrophoresis 25, 2539-2544 (2004).

- 30 Wu J, Lenchik NJ, Pabst M J, Solomon SS, Shull J, Gerling IC. Functional characterization of two-dimensional gel-separated proteins using sequential staining. Electrophoresis 26, 225-237 (2005).

- 31 Nijtmans LG, H enderson N S, H olt IJ. Blue native electrophoresis to study mitochondrial and other protein complexes. M ethods 26, 327-334 (2002).

- 32 Schagger $H$, von Jagow G. Blue native electrophoresis for isolation of membrane protein complexes in enzymatically active form. Anal. Biochem. 199, 223-231 (1991).

- 33 Fandino AS, Raisl, Vollmer M, Elgass H, Schagger $\mathrm{H}$, Karas M. LC-nanosprayM S/M S analysis of hydrophobic proteins from membrane protein complexes isolated by blue native electrophoresis. J. M ass Spectrom. 40, 1223-1231 (2005).

- 34 Karas M, H illenkamp F. Laser desorption ionization of proteins with molecular masses exceeding 10,000 daltons. Anal. Chem. 60, 2299-2301 (1988).

- 35 Fenn JB, M ann M, M eng CK, Wong SF, W hitehouse $C M$. Electrospray ionization for mass spectrometry of large biomolecules. Science 246, 64-71 (1989).

- Nobel Prize winner John Fenn's article describing the soft ionization method electrospray ionization.

- 36 Ishihama Y. Proteomic LC-M S systems using nanoscale liquid chromatography with tandem mass spectrometry. J. Chromatogr. A 1067, 73-83 (2005).

- 37 N agele E, Vollmer M, H orth P. Two-dimensional nano-liquid chromatography-mass spectrometry system for applications in proteomics. J. Chromatogr. A 1009, 197-205 (2003).

- Extensive review about 2D liquid chromatography mass spectrometry.
-38 H usson SJ, Clynen E, Baggerman G, De Loof A, Schoofs L. Discovering neuropeptides in $C$ aenorhabditis elegans by two dimensional liquid chromatography and mass spectrometry. Biochem. Biophys. Res. Commun. 335, 76-86 (2005).

- 39 Baggerman G, Vierstraete $E$, D e L oof A, Schoofs L. Gel-based versus gel-free proteomics: a review. Comb. Chem. High Throughput Screen. 8, 669-677 (2005).

40 Washburn M P, Wolters D, Yates JR III. $L$ arge-scale analysis of the yeast proteome by multidimensional protein identification technology. N ature Biotechnol. 19, 242-247 (2001).

-41 Ross PL, Huang YN, M archese JN et al. Multiplexed protein quantitation in Saccharomyces cerevisiae using amine-reactive isobaric tagging reagents. M ol. Cell. Proteomics 3, 1154-1169 (2004)

-42 Ong SE, Blagoev B, K ratchmaroval et al. Stable isotope labeling by amino acids in cell culture, SI LAC, as a simple and accurate approach to expression proteomics. M ol. Cell. Proteomics 1, 376- 386 (2002).

${ }_{43}$ Kirkpatrick DS, Gerber SA, Gygi SP. The absolute quantification strategy: a general procedure for the quantification of proteins and post-translational modifications. M ethods 35, 265-273 (2005).

44 Gygi SP, Rist B, Gerber SA, Turecek F, Gelb M H, Aebersold R. Q uantitative analysis of complex protein mixtures using isotope-coded affinity tags. N ature Biotechnol. 17, 994-999 (1999).

- First publication on the isotope-coded affinity tag strategy.

-45 Zhou H, Ranish JA, Watts JD, Aebersold R. $Q$ uantitative proteome analysis by solidphase isotope tagging and mass spectrometry. $\mathrm{N}$ ature Biotechnol. 20, 512-515 (2002).

46 M unchbach M, Q uadroni M, M iotto G, James P. Q uantitation and facilitated de novo sequencing of proteins by isotopic $\mathrm{N}$-terminal labeling of peptides with a fragmentation-directing moiety. Anal. Chem. 72, 4047-4057 (2000).

- 47 Liu Y, Patricelli M P, Cravatt BF. Activity-based protein profiling: the serine hydrolases. Proc. N atl Acad. Sci. U SA 96, 14694-14699 (1999).

48 G reenbaum D, M edzihradszky KF, Burlingame A, Bogyo M.

Epoxide el ectrophiles as activity-dependent cysteine protease profiling and discovery tools. Chem. Biol. 7, 569-581 (2000).

$\checkmark 49 \mathrm{O}$ da Y, N agasu T, C hait BT. Enrichment analysis of phosphorylated proteins as a tool for probing the phosphoproteome. $N$ ature Biotechnol. 19, 379-382 (2001).
-50 Zhang H, Li XJ, M artin D B, A ebersold R. Identification and quantification of $\mathrm{N}$-linked glycoproteins using hydrazide chemistry, stable isotope labeling and mass spectrometry. N ature Biotechnol. 21, 660-666 (2003).

-51 O da Y, H uang K, Cross FR, Cowburn D, Chait BT. Accurate quantitation of protein expression and site-specific phosphorylation. Proc. N atl Acad. Sci. U SA 96, 6591-6596 (1999)

-52 Snijders AP, de Vos M G, de Koning B, Wright PC. A fast method for quantitative proteomics based on a combination between two-dimensional electrophoresis and $15 \mathrm{~N}$-metabolic labelling. Electrophoresis 26, 3191-3199 (2005).

53 Ong SE, Kratchmarova I, M ann M. Properties of ${ }^{13} \mathrm{C}$-substituted arginine in stable isotope labeling by amino acids in cell culture (SILAC). J. Proteome Res. 2, 173-181 (2003).

-54 Ong SE, M ittler G, M ann M. Identifying and quantifying in vivo methylation sites by heavy methyl SILAC. $N$ ature M ethods 1, 119-126 (2004).

-55 Yao X, Freas A, Ramirez J, D emirev PA, Fenselau C. Proteolytic ${ }^{18} \mathrm{O}$ labeling for comparative proteomics: model studies with two serotypes of adenovirus. Anal. Chem. 73, 2836-2842 (2001).

56 Stewart II, Thomson T, Figeys D. ${ }^{18} \mathrm{O}$ labeling: a tool for proteomics. Rapid Commun. M ass Spectrom. 15, 2456-2465 (2001).

-57 Barr JR, M aggio VL, Patterson D G Jr et al. Isotope dilution - mass spectrometric quantification of specific proteins: model application with apolipoprotein A-I. Clin. Chem. 42, 1676-1682 (1996).

-58 Ciechanover A, H eller $\mathrm{H}$, Elias $\mathrm{S}, \mathrm{H}$ aas AL, $\mathrm{H}$ ershko A. ATP-dependent conjugation of reticulocyte proteins with the polypeptide required for protein degradation. Proc. N atl Acad. Sci. U SA 77, 1365-1368 (1980)

59 Tyers $M$, Jorgensen P. Proteolysis and the cell cycle: with this RIN G I do thee destroy. Curr. 0 pin. Genet. D ev. 10, 54-64 (2000).

-60 Apweiler R, H ermjakob H, Sharon N. $\mathrm{O} n$ the frequency of protein glycosylation, as deduced from analysis of the SW ISS-PROT database. Biochim. Biophys. Acta 1473, 4-8 (1999).

-61 M ann M, Jensen O N . Proteomic analysis of post-translational modifications. $N$ ature Biotechnol. 21, 255-261 (2003).

- Excellent review about the importance and identification possibilities of post-translational modifications. 
-62 Reinders J, Lewandrowski U, M oebius J, Wagner $Y$, Sickmann A. Challenges in mass spectrometry-based proteomics. Proteomics 4, 3686-3703 (2004).

-63 Aebersold R, Goodlett DR. $M$ ass spectrometry in proteomics. Chem. Rev. 101, 269-295 (2001).

-64 Tang N, Tornatore P, Weinberger SR. Current developments in SELDI affinity technology. M ass Spectrom. Rev. 23, 34- 44 (2004).

-65 Hess JL, Blazer L, Romer T, Faber L, Buller RM , BoyleM D. Immunoproteomics. J. Chromatogr. B Analyt. Technol. Biomed. Life Sci. 815, 65-75 (2005).

-66 Vitzthum F, Behrens F, Anderson N L, Shaw JH. Proteomics: from basic research to diagnostic application. A review of requirements and needs. J. Proteome Res. 4 1086- 1097 (2005).

-67 Winer S, Tsui H, Lau A et al. Autoimmune islet destruction in spontaneous Type 1 diabetes is not $\beta$-cell exclusive. N ature M ed. 9, 198-205 (2003).

-68 Wright GL Jr. SELDI proteinchip M S: a platform for biomarker discovery and cancer diagnosis. Expert Rev. M ol. Diagn. 2, 549-563 (2002).

-69 Combaret V, Bergeron C, Brejon S et al. Protein chip array profiling analysis of sera from neuroblastoma patients. Cancer $L$ ett. 228, 91-96 (2005).

-70 Petricoin EF, Ardekani AM, H itt BA et al. U se of proteomic patterns in serum to identify ovarian cancer. Lancet 359 , 572-577 (2002).

71 deSeny D, Fillet M, M euwis M A et al. Discovery of new rheumatoid arthritis biomarkersusing the surface-enhanced laser desorption/ionization time of-flight mass spectrometry ProteinC hip approach. Arthritis Rheum. 52, 3801-3812 (2005).

72 Baggerly KA, M orris JS, Coombes KR. Reproducibility of SELDI-TO F protein patterns in serum: comparing datasets from different experiments. Bioinformatics 20 , 777-785 (2004).

73 Mathis D, Vence L, Benoist C. $\beta$-cell death $>_{84}$ during progression to diabetes. $\mathrm{N}$ ature 414 , 792-798 (2001).

-74 StoffelsK, O verbergh L, Giulietti A et al. NOD macrophages produce high levels of inflammatory cytokines upon encounter of apoptotic or necrotic cells. J. Autoi mmun. 23, 9-15 (2004).

-75 Kutlu B, Cardozo AK, D arville M I et al. $D$ iscovery of gene networks regulating cytokine-induced dysfunction and apoptosis in insulin-producing IN S- 1 cells. Diabetes 52, 2701-2719 (2003).
76 Cardozo AK, Proost P, Gysemans C, $C$ hen $M C, M$ athieu $C$, Eizirik D L. $\mathrm{IL}-1 \beta$ and IFN $-\gamma$ induce the expression of diverse chemokines and IL-15 in human and rat pancreatic islet cells, and in islets from pre-diabetic N O D mice. Diabetologia 46, 255-266 (2003).

-77 Rieneck K, Bovin LF, Josefsen K, Buschard K, Svenson M, Bendtzen K. $M$ assive parallel gene expression profiling of RIN m5F pancreatic islet $\beta$-cells stimulated with interleukin-1 $\beta$. APM IS 108, 855-872 (2000).

-78 Nielsen K, Kruhoffer M, O rntoft T et al. $G$ ene expression profiles during $\beta$ cell maturation and after IL-1 $\beta$ exposure reveal

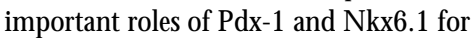
IL-1 $\beta$ sensitivity. D iabetologia 47, 2185-2199 (2004).

-79 C ardozo AK, H eimberg $\mathrm{H}, \mathrm{H}$ eremans $\mathrm{Y}$ et al. A comprehensive analysis of cytokine-induced and nuclear factor- $\kappa \mathrm{B}$-dependent genes in primary rat pancreatic $\beta$-cells. J. Biol. Chem. 276, 48879-48886 (2001).

- $80 \mathrm{H}$ eimberg $\mathrm{H}$, H eremans $\mathrm{Y}$, Jobin $\mathrm{C}$ et al. Inhibition of cytokine-induced N F-кB activation by adenovirus-mediated expression of a N F-kB super-repressor prevents $\beta$-cell apoptosis. Diabetes 50 , 2219-2224 (2001).

-81 N ielsen K, Sparre T, Larsen M R et al. Protein expression changes in a cell system of $\beta$-cell maturation reflect an acquired sensitivity to IL-1 $\beta$. D iabetologi a 47, 62-74 (2004).

$\$ 2$ John NE, Andersen H U, Fey SJ et al. Cytokine or chemically derived nitric oxide alters the expression of proteins detected by two-dimensional gel electrophoresis in neonatal rat islets of Langerhans. D iabetes 49, 1819-1829 (2000).

-83 Larsen PM , Fey SJ, Larsen M R et al. Proteome analysis of interleukin-1 $\beta$-induced changes in protein expression in rat islets of $L$ angerhans. D iabetes 50, 1056-1063 (2001).

$84 \mathrm{HuX}$, Friedman D, Hill S et al. Proteomic exploration of pancreatic isletsin mice null for the $\alpha 2 \mathrm{~A}$ adrenergic receptor. J. M ol. Endocrinol. 35, 73-88 (2005).

-85 Sparre T, Christensen U B, G otfredsen CF et al. C hanges in expression of IL-1 $\beta$ influenced proteins in transplanted islets during development of diabetes in diabetes-prone BB rats. D iabetologia 47, 892-908 (2004).

86 Christensen UB, Larsen PM , Fey SJ et al. Islet protein expression changes during diabetes development in islet syngrafts in
$B B-D P$ rats and during rejection of $B B-D P$ islet allografts. Autoimmunity 32, 1-15 (2000).

$\$ 87$ Arif S, Tree TI, Astill TP et al. Autoreactive $T$ cell responses show proinflammatory polarization in diabetes but a regulatory phenotype in health. J. Clin. Invest 113, 451-463 (2004).

$88 \mathrm{M}$ annering $\mathrm{SI}, \mathrm{H}$ arrison $\mathrm{LC}$, Williamson NA et al. The insulin A-chain epitope recognized by human $T$ cells is posttranslationally modified. J. Exp. M ed. 202(9), 1191-1197 (2005).

89 Wittke $S, M$ ischak $H$, Walden $M$, Kolch W, Radler T, W iedemann K. Discovery of biomarkers in human urine and cerebrospinal fluid by capillary electrophoresis coupled to mass spectrometry: towards new diagnostic and therapeutic approaches. Electrophoresis 26, 1476-1487 (2005).

-90 Baekkeskov S, Warnock G, Christie M , Rajotte RV, Larsen PM , Fey S.

Revelation of specificity of $64 \mathrm{~K}$ autoantibodies in ID D M serums by high-resolution 2-D gel electrophoresis. Unambiguous identification of $64 \mathrm{~K}$ target antigen. D iabetes 38, 1133-1141 (1989).

-91 Andersen HU, Larsen PM, Fey SJ, Karlsen AE, M andrup-Poulsen T, N erup J. Two-dimensional gel electrophoresis of rat islet proteins. Interleukin $1 \beta$-induced changes in protein expression are reduced by L-arginine depletion and nicotinamide. Diabetes 44, 400-407 (1995).

$\checkmark 92$ Andersen HU, Fey SJ, Larsen PM et al. Interleukin- $1 \beta$ induced changes in the protein expression of rat islets: a computerized database. Electrophoresis 18, 2091-2103 (1997).

93 Hughes JH, Colca JR, Easom RA, Turk J, $M$ CD aniel M L. Interleukin 1 inhibits insulin secretion from isolated rat pancreatic islets by a process that requires gene transcription and $\mathrm{mRN} A$ translation. J. Clin. Invest 86, 856-863 (1990).

94 Sparre T, Christensen UB, M ose LP et al. IL-1 $\beta$ induced protein changes in diabetes prone $B B$ rat islets of $L$ angerhans identified by proteome analysis. Diabetologia 45 , 1550-1561 (2002).

-95 Sparre T, Reusens B, Cherif $\mathrm{H}$ et al. Intrauterine programming of fetal islet gene expression in rats - effects of maternal protein restriction during gestation revealed by proteome analysis. D iabetologia 46 , 1497-1511 (2003).

96 Sparre T, Bergholdt R, N erup J, Pociot F. Application of genomics and proteomics in Type 1 diabetes pathogenesis research. Expert Rev. M ol. D iagn. 3, 743-757 (2003). 
-97 Sparre T, Larsen M R, H eding PE, $K$ arlsen $A E$, Jensen $O N$, Pociot $F$. Unraveling the pathogenesis of Type 1 diabetes with proteomics: present and future directions. $\mathrm{M}$ ol. Cell. Proteomics 4, 441-457 (2005).

- Excellent review on the applications of proteomics in Type 1 diabetes.

-98 Sanchez JC, C hiappe D, Converset V et al. The mouse SW ISS-2D PAGE database: a tool for proteomics study of diabetes and obesity. Proteomics 1, 136-163 (2001).

99 Sanchez JC, Converset V, N olan A et al. Effect of rosiglitazone on the differential expression of diabetes-associated proteinsin pancreatic islets of C 57BI/ 6 lep/lep mice. M ol. Cell. Proteomics 1, 509-516 (2002).

100 Nicolls M R, D 'Antonio JM, Hutton JC, Gill RG, Czwornog JL, D uncan M W. Proteomics as a tool for discovery: proteins implicated in Alzheimer's disease are highly expressed in normal pancreatic islets. J. Proteome Res. 2, 199-205 (2003).

- 101 Ahmed M, Bergsten P. Glucose induced changes of multiple mouse islet proteins analysed by two-dimensional gel electrophoresis and mass spectrometry. D iabetologia 48, 477-485 (2005).

- 102 Thongboonkerd V, Barati M T, M cLeish KR et al. Alterations in the renal elastin-elastase system in Type 1 diabetic nephropathy identified by proteomic analysis. J. Am. Soc. Nephrol. 15, 650-662 (2004).

$103 \mathrm{Hu}$ L, Evers S, Lu ZH, Shen Y, Chen J. Two-dimensional protein database of human pancreas. Electrophoresis 25, 512-518 (2004).

104 Ahmed M, Forsberg J, Bergsten P. Protein profiling of human pancreatic islets by two-dimensional gel electrophoresis and mass spectrometry. J. Proteome Res 4, 931-940 (2005).

- Study on human islets of Langerhans using gel-based proteomics.

- 105 M eier M, Kaiser T, H errmann A et al. Identification of urinary protein pattern in Type 1 diabetic adolescents with early diabetic nephropathy by a novel combined proteome analysis. J. D iabetes Complications 19, 223-232 (2005).

- 106 Rossing K, M ischak H, Parving H H et al. Impact of diabetic nephropathy and angiotensin II receptor blockade on urinary polypeptide patterns. Kidney Int. 68 , 193-205 (2005).
107 Westman-Brinkmalm A, Karlsson G, Brive LM et al. Analysis of proteins from a glioma cell line by using micro-scale solution isoelectric focusing in combination with liquid chromatography/tandem mass spectrometry. Rapid Commun. M ass Spectrom. 19, 3651-3658 (2005).

108 Poland J, Cahill M A, Sinha P. I soelectric focusing in long immobilized $\mathrm{pH}$ gradient gels to improve protein separation in proteomic analysis. Electrophoresis 24, 1271-1275 (2003).

109 Poznanovic S, Schwall G, Zengerling H, $\mathrm{C}$ ahill $\mathrm{MA}$. Isoelectric focusing in serial immobilized $\mathrm{pH}$ gradient gels to improve protein separation in proteomic analysis. Electrophoresis 26, 3185-3190 (2005).

110 Poznanovic S, Wozny W, Schwall GP et al. $D$ ifferential radioactive proteomic analysis of microdissected renal cell carcinoma tissue by $54 \mathrm{~cm}$ isoelectric focusing in serial immobilized $\mathrm{pH}$ gradient gels. J. Proteome Res. 4, 2117-2125 (2005).

111 Soloviev M, Finch P. Peptidomics, current status. J. Chromatogr. B Analyt. Technol. Biomed. Life Sci. 815, 11-24 (2005).

112 Baggerman G, Verleyen P, Clynen E, H uybrechts J, D e Loof A, Schoofs L. Peptidomics. J. Chromatogr. B Analyt. Technol. Biomed. Life Sci. 803, 3-16 (2004).

-. Very good review about a field of research that will most probably grow exponentally in the coming years.

113 Ivanov VT, Yatskin O N. Peptidomics: a logical sequel to proteomics. Expert Rev. Proteomics 2, 463-473 (2005).

114 Schoofs L, Baggerman G. Peptidomics in D rosophila melanogaster. Brief Funct. Genomic. Proteomic. 2, 114-120 (2003).

115 H ummon AB, Amare A, Sweedler JV. $D$ iscovering new invertebrate neuropeptides using mass spectrometry. $M$ ass Spectrom. Rev. 25, 77- 98 (2006).

116 Rahman SM, Shyr Y, Yildiz PB et al. Proteomic patterns of preinvasive bronchial lesions. Am. J. Respir. Crit. Care M ed. 172, 1556- 1562 (2005).

117 Zheng Y, Xu Y, YeB et al. Prostate carcinoma tissue proteomics for biomarker discovery. C ancer 98 , 2576-2582 (2003).
118 Reyzer M L, H sieh Y, N g K, Korfmacher WA, Caprioli RM . Direct analysis of drug candidates in tissue by matrix-assisted laser desorption/ionization mass spectrometry. J. M ass Spectrom. 38, 1081-1092 (2003).

-119 Chaurand P, Sanders M E, Jensen RA, Caprioli RM . Proteomics in diagnostic pathology: profiling and imaging proteins directly in tissue sections. Am. J. Pathol. 165, 1057-1068 (2004).

120 Caldwell RL, Caprioli RM . Tissue profiling by mass spectrometry: a review of methodology and applications. M ol. Cell. Proteomics 4, 394-401 (2005).

-. D escribes different methodologies for tissue profiling, including examples in clinical applications.

\section{Websites}

201 SWISS 2D-PAGE. M ap Selection: ISLETS_M OUSE www. expasy.org/cgi-bin/map2/def? SLETS_ MOUSE

202 MEDLINE www.ncbi.nlm.nih.gov/entrez/query.fcgi

\section{Affiliations}

- Wannes D'H ertog

Laboratory for Experimental M edicine \& Endocrinology (LEGEN D O), U niversity H ospital Gasthuisberg, H erestraat 49 Catholic University of Leuven, Leuven, Belgium

Tel.: +32 16346030

Fax: +3216346035

wannes.dhertog@bio.kuleuven.be

- Chantal M athieu, M D, PhD

Laboratory for Experimental M edicine \& Endocrinology (LEGEND O), U niversity H ospital Gasthuisberg, H erestraat 49 Catholic University of Leuven, Leuven, Belgium

Tel.: +32 16345970

Fax: +32 16345934

chantal.mathieu@med.kuleuven.be

- Lut 0 verbergh, PhD

Laboratory for Experimental M edicine \& Endocrinology (LEGENDO), U niversity $\mathrm{H}$ ospital Gasthuisberg, Herestraat $49 \mathrm{C}$ atholic University of Leuven, Leuven, Belgium

Tel.: +3216346163

Fax: +32 16346035

lut.overbergh@med.kuleuven.be 